\title{
Effect Of Green Accounting On Financial Performance Of Oil And Gas Companies In Nigeria
}

BY

\section{NWAFOR CHIDI BENSON}

Department of Accounting, Faculty of Management Sciences, University Of Calabar, P.M.B. 1115, Calabar, Cross River State, Nigeria.

chidibenson@gmail.com

\section{Asuquo, Akabom Ita}

Department of Accounting, Faculty of Management Sciences, University Of Calabar, P.M.B. 1115, Calabar, Cross River State, Nigeria.

drakabom3@gmail.com

\section{Inyang, Ethel Ohanya}

Department of Accounting, Faculty of Management Sciences, University Of Calabar, P.M.B. 1115, Calabar, Cross River State, Nigeria. ethelinyang@gmail.com

Fadenipo A. Adesola Department of Accounting, Faculty of Management Sciences, University of Calabar, P.M.B. 1115, Calabar, Cross River State, Nigeria.

horshinaiki@yahoo.com

\section{Abstract}


The study examined the effect of green accounting on the financial performance of oil and gas companies 2010-2020. The specific objectives were to determine the effect of: environmental cost accounting and green management accounting on the financial performance of oil and gas companies in Nigeria. A quantitative technique was adopted and Ex post facto research design was employed for the study. Data were obtained from annual reports and accounts of the companies for the periods 2010 to 2020. The hypotheses were tested using regression analysis with aid of e-view 9.0. The results showed that environmental cost accounting has a significant effect on the financial performance of oil and gas companies. Also, the study found that green management accounting has significant effect on the financial performance of oil and gas firms. Therefore, the paper recommended that management of oil and gas companies in Nigeria should pay particular attention to environmental cost accounting to enhance the firm's operating environment and the financial performance of the companies. Also, since most oil and gas companies hardly report their environmental activities, the government should make environmental reporting in annual reports compulsory thereby passing legislation which will compel companies to integrate environmental issues into their strategic planning process; and the publication of environmental accounting standards both locally and internationally which can be reviewed continually to ensure dynamism in compliance.

Keywords: Green accounting, environmental costs, financial performance, oil and gas companies, returns on assets, returns on equity.

\section{Introduction}

Green accounting is a type of accounting that attempts to factor environmental costs into the financial results of operations. It has been argued that gross domestic product ignores the environment and therefore decision makers need a revised model that incorporates green 
accounting. Environmental pollution is one of the problems facing the world today, due to its impact on society, nature and performance (Khan \& Ghouri, 2011). The phenomenon of environmental pollution has received increasing attention in recent times, especially in light of the industrial progress in the contemporary world and the diversity of sources of pollution, and the attempt of industrial companies, particularly oil and gas firms to get rid of its waste is harmful to the environment and people (Chinwe, 2013). As a result of the development of interest in environmental performance as one of the foundations of development in any country, non-use of modern scientific methods that analyse environmental costs and provide detailed information on those costs and the efforts and amounts that companies bear for the purpose of environmental protection will give guaranteed results on the extent of their success or failure (Nas, 2016). Therefore, new concepts of accounting emerged, such as green accounting, and the names have multiplied across stages of concern for the environment (accounting for a sustainable environment, environmental accounting, environmental impact accounting, social responsibility accounting, etc.), and then the concept of green accounting emerged when it was considered the subject of the system (Moorthy \& Yacob, 2013). The environmental protection is one of the foundations of economic development, and that preserving the environment and resources is a right for society, and environmental issues have become a social matter at the local, national and international levels, so the matter needed to develop accounts in line with the environmental problem at the level of the institution and the whole economy (Portney, 2013). According to Malik \& Mittal (2015), Green accounting is important for developing economies, this is because green accounting helps in saving environmental and development problems. Environmental accounting will help countries in addressing the economic problems associated with climate change. For instance, according to the World Bank, the world losses a significant amount of money due to environmental changes. Green accounting would help in solving environmental changes 
leading to improved performance for companies and firms operating in developing countries. Firms that have adopted green accounting have led to reduced operational costs during environmental changes.

However, a lot of government enactments, laws and regulations on environmental protection have been made in several nations of the world including Nigeria. In the light of the awakening to environment protection, various laws and regulations such as the Environmental Impact Assessment Act, 1992 and the Department of Petroleum Resources (DPR) Environmental Guidelines and Standards for the Petroleum Industry in Nigeria (Chiamogu \& Okoye, 2020) were enacted. These require corporate managements to consider the environmental implications of all internal decisions of their managements. Also, all organizations monitored by environmental policy agencies in Nigeria are expected to demonstrate much consideration in decision making. Environmentalists agree that it could be more cost efficient and beneficial for companies to acquire pollution prevention or clean technology than those of pollution clean-up. It is also observed that in environmental regulations, there is a shift from the 'command and control' approach to market-driven forms in which pollution prevention alternatives are replacing pollution cleaning approach. It follows therefore, that determining the appropriate pollution prevention approach may lead to additional decisions to be taken by management. Such decisions may include proper environmental cost and green management accounting to reduce the impact of the firm's operation on the environment. However, most oil and gas firms pay little or no attention to issues of green or environmental accounting, with dire consequences on the environment and host community. Therefore, in the light of the background of increasing environmental attention, and the fact that the oil and gas sectors having profound production impact on the environment, the study explores the effect of green accounting on the financial performance oil and gas companies in Nigeria. 
The raising effect of oil and gas firm's operations on the environment have continue to post a challenge on the people and the host communities. This is due to the lack of a clear framework such as the green accounting standard that could ensure that firms are accountable for their actions in the environment. Green or environmental accounting involves the process of communicating the social and environmental effects of organizations' economic actions to particular interest group within society and to society at large. As such it involves extending the accountability of organizations (particularly companies) beyond the traditional role of providing a financial account to the shareholders. Such an extension is predicated upon the assumption that companies do have wider responsibilities than simply to make money for the shareholders (Saman, 2019). In this case it is a comprehensive approach to ensure good corporate governance that includes transparency in its social activities. The problem is that conventional approaches of cost accounting have become inadequate since conventional accounting practices have ignored important environmental costs and activities impacting consequences on the environment. Corporate neglect and avoidance of environmental costing leave gap in financial information reporting. There is no completeness and correctness of fair view to users of financial information, such as shareholders, environmental regulatory agencies, environmentalists and potential financial investors.

However, there are currently only limited requirements for any formal identification or reporting with regard to environmental assets, liabilities or contingencies. The key problem is that there are few formalized definitions of what environmental assets or environmental contingencies are, although some progress has been made in this area. There is no clear stipulation of environmental issues in standards as a basic requirement, since no such specific standard exists, and the present standards include minimal guidelines concerning environmental issues. This implies the problem of such comparison among the reports, inadequate management of environmental costs and different calculating methods among 
firms. Also, the lack of effective green management accounting, green cost accounting and the absence of clear environmental accounting standards affect green account practice in oil and gas firms and makes comparison between firms not possible because method of accounting is different. It is on this ground that the study was carried out to provide solutions to the research problems while also contributing in filling the literature gap on the effect of green accounting on the financial performance of oil and gas firms in Nigeria.

The objective of this paper was to investigate the effect of green accounting on financial performance of oil and gas companies Nigeria 2010-2020

\subsection{THEORETICAL FRAMEWORK AND LITERATURE REVIEW}

\subsection{Stakeholders' theory}

In an organization, there are basically two types of stakeholders (Internal and external). Most internal stakeholder includes management, employee and board while external stakeholder include shareholders, communities, creditors, debtors/customers, government agencies, and environment (Johnson-Rokosu \& Olanrewanju, 2016). Basically, stakeholder theory is based on proposition that a firm 's success or otherwise depends on a successful management of all the relationships that a firm has with its stakeholders (Uwuigbe \& Jimoh, 2012). It is argued that stakeholder theory is one of the theories that seeks to explain the practice of presenting social information, focused on the role it can play in relations between organizations, governments, individuals, associations and societies in general (Magnaghi \& Aprile, 2014). Gray et al (2002), reported that from an organizational point of view, stakeholders' theory is based on a model of accountability for all actors, be it normative, descriptive or the explanatory power they hold in the context of CSR; and includes the responsibilities of the company and the transparent nature of its activities. 
A crucial element that the company can use to manage stakeholder relationships is precisely the information (financial, sustainability, or both) managed to gain the support and approval of corporate strategy from the stakeholders, without raising an objection. Voluntary disclosure is amply justified by the stakeholder theory and consequently the theory of legitimacy that is considered an appropriate means to maintain and develop relations between the various interest-bearing groups and the company. Furthermore, stakeholder provides another theoretical framework for explaining the relationship between various stakeholders and management; and potentially useful in examining or influencing corporate social disclosures or sustainability environmental reporting by organization in the annual corporate reports. In line with this, one of the genuine acknowledgments by industry of a duty to the environment is one reason for the growth of voluntary environmental guidelines and policies. Second, these codes are a response to shareholder, customer, interest group and community pressure on companies to be transparent and accountable in environmental management, allowing industry to demonstrate environmental responsibility and enhancing public relations. Third, companies have adopted these co-operative and flexible approaches to environmental regulation in order to avoid prescriptive and costly command and control mechanisms.

\subsection{Concept of green accounting}

Green or environmental accounting is a term with a variety of meanings. In many contexts, green accounting is taken to mean the identification and reporting of environment specific costs (Nkwoji, 2021). Green accounting is a method of measuring, in economic terms, the performance of any type of organization in relation to the environment. The goal is to provide information about the company's operational performance based on environmental protection. Conventional accounting only provides economic information that is financial in nature to shareholders and bondholders for decision making. Performance measures need to 
be increased to improve existing performance measures. Environmental impacts need to be reported as a manifestation of responsibility towards stakeholders (Astuti, 2012). Green accounting or environmental accounting aims at achieving sustainable development, maintaining a favorable relationship with the community, and pursuing effective and efficient environmental conservation activities. The accounting procedures allow a company to identify the cost of environmental conservation during the normal course of business, identify benefit gained from such activities, and provide the best possible means of quantitative measurement, in monetary value or physical units, and support the communication of its results.

Green accounting is a type of accounting that attempts to incorporate environmental costs into the financial results of operations (Rewadikar, 2014). It is accounting for any costs and benefits that arise from change to a firm's, products and processes where the change also involves a change in environmental impact. Green accounting is a relatively new concept which aims to include in the traditional measurement of economic development the cost for using the environment as inputs to production and as a sink for wastes. From the point of view of green accounting, land, water, and other natural resources are treated as inputs and assets in the production of goods and services of an entity (Virola, De Perio \& Angeles, 2000). Green accounting or environmental accounting is the practice of incorporating principles of environmental management and conservation into reporting practices and cost/benefit analyses (Rewadikar, 2014). Environmental accounting allows a business to see the impact of economically sustainable practices in everything. It allows accountants to report on the economic impact of those decisions to stakeholders so as to allow for proactive decision making about processes that simultaneously meet environmental regulations while adding to the bottom line. 
Green accounting according to Lewis and Chopparapu (2017), mainly focuses on the role in which an enterprise has toward the environment. Environmental change has a bearing change in not only the environment but also in the economy. A suitable environment has a positive impact on the business sector by creating an appropriate environment for enterprising (Hecht, 2012). Green accounting examines how the environment affects the financial accounting system in terms of costs and benefits. It is an approach to measure and communicate information related to environmental activities of economic units with environmental impact to the parties concerned and society in a manner that enables control and evaluation of their environmental performance (Moorthy \& Yacob, 2013). Green accounting has led to sustainable development by creating a peaceful environment for the enterprise (Gray \& Laughlin, 2012). 2.3 Forms of green accounting

Green accounting involves estimation of environmental expenditures/cost, capitalization of those environmental expenditures, identification of environmental liabilities and measurement of environmental liabilities. There are several forms of green or environmental accounting including:

Green management accounting: Green or environmental management accounting is the identification, prioritization, quantification or qualification, and incorporation of environmental costs into business decisions (Astuti, 2012). Green management accounting uses data about environmental costs and performance for business decisions. It collects cost, production, inventory, and waste cost and performance for business decisions. Environmental management accounting thus represents a combined approach which provides for the transition of data from financial accounting and cost accounting to increase material efficiency, reduce environmental impact and risk, and reduce costs of environmental protection 
Green or environmental cost accounting: The environmental cost accounting deals with environmental costs in order to reach the full cost accounting, i.e. the identification, evaluation, and allocation of conventional costs, environmental costs, and social costs to processes, products, activities, or budgets. In some organizations, accountants are held responsible to identify and track green costs often times working with site, research and development, and production managers when planning their budgets. In the past, such costs were buried in overhead preventing a clear picture of the cost savings and benefits to the product, process, system or facility responsible for the green initiatives. Green accounting help management recognize that the tax benefits, rebates and lower costs of being environmentally friendly add up to a real bottom-line reward for doing the right thing (Eilola, 2017).

Environmental financial accounting: Environmental cost accounting, environmental management accounting, ecological accounting and natural resource accounting. Environmental financial accounting aims to the true disclosure in financial statements in the end of period. That is including environmental dimension in the published sheets of operations.

Environmental expenditures/costs: These are expenses or costs related to environmental measures including production-related costs and product research and development expenditures which are incurred primarily for ensuring protection of environment. Total environmental expenditures can be classified into six categories such as capital investment, operating costs, research and development cost, environment administration and planning, expenditures for remedial measures and recovery measures (Eze, 2021).

Ecological accounting: Ecological cost accounting is used to refer to the preparation of accounts according to physical data only. In this respect, ecological accounting is mainly 
used to prepare an asset management plans at local administration level. Such plans provide a tool to evaluate the condition and life cycle of any particular physical asset.

Natural resource accounting: Natural resource accounting is called after inclusion of environmental aspects into the system of national accounts. Emphasis is given to natural assets, deterioration in its quality in order to get an environmentally adjusted economic indicator such as environmental gross national income (Rewadikar, 2014).

\subsection{Financial performance}

Financial performance is a subjective measure of how well a firm can use assets from its primary mode of business and generate revenues. It shows the general well-being of a firm and its true financial position (Eze, 2021). Financial performance can be looked at, as the level of performance of an organization at a point in time. This could be measured in terms of overall profits and losses or asset utilization. According to Iliemena and Okolocha (2019) the measures of financial performance of an organization are as varied as the motive for the measurement. Organisational financial performance is measured to give the account of stewardship by the management team to the shareholders. The key aspect of this involves measuring the profitability, return on investment, return on asset and growth prospect of a company. The measurement of the effect of environmental accounting on performance examines the nature of the relationship between some indicator of environmental reporting or performance with the company's financial performance obtained from the accounting information such as the historical audited financial statements of the respective companies. Financial performance is commonly used as an indicator of a firm's financial health over a given period of time. In this study, financial performance is measured return on equity and return on asset.

\subsection{Returns on equity}


This ratio measures the overall performance of an entity; it shows the earning power of investors' book value, often used in comparing two or more entities in an industry. A high return on equity is an indication that an entity accepts a strong investment opportunity and employs effective expense management. Return on equity is net profit after tax and preference dividend scaled by the number of shares. Studies have shown that green accounting practices increased earnings of firms. Almalik (2020) in their study revealed that corporate social spending improves the return on equity of firms. Eze (2021) reported a positive relationship existing between corporate responsibility and return on equity.

\subsection{Returns on assets}

As one of the traditional accounting and profitability measures employed to measure financial performance, return on assets shows whether a company is able to generate an adequate return on the assets employed. In a study on environmental disclosure and financial performance of food and beverage companies in Nigeria by Ezeagba et al (2017), it was revealed that there is a significant relationship between environmental accounting disclosure and return on assets.

\subsection{Methodology}

The research design employed in this study is the ex-post facto research design, in order to establish a relationship between green accounting and financial performance oil and gas companies. This study was treated as ex-post facto research since it relied on historical data. This is appropriate because ex-post facto research aims at measuring and establishing the relationship between one variable and another or the effect of one variable on another, in which the variables involved are not manipulated by the researcher (Kothari \& Garg, 2014).

The population of this study consist of the eleven (11) oil and gas companies listed on the Nigerian Stock Exchange as at 31st December, 2010. They include; Japaul Oil \& Maritime 
Services Plc, Oando Plc, Beco Petroleum Products Plc, Capital Oil Plc, Conoil Plc, Rak Unity Petroleum Plc, Eterna Plc, Forte Oil Plc, Mobil Oil Plc, MRS Oil Nigeria Plc and Total Nigeria Plc. A census of the eleven Oil and Gas companies were used. Data were gathered from the published financial statements of the eleven companies from 2010-2020. The reason for the choice of this time frame is availability of published annual report and accounts of the selected companies.

The data analysis for the study took the form of descriptive statistics and inferential statistics. This research work adopted the panel least square (PLS) regression analysis with longitudinal (panel) regression using E-Views 9.0 statistical software. The reason for adopting panel data regression is because of the number of Oil and Gas firms and the period of time involved.

\subsection{Results and analysis}

Table 1 presents the descriptive statistics for the different variables of the study with an observation of 121 (i.e 11 companies x 11 years, 2010-2020). Mean is the most commonly used measure of central tendency. The standard deviation shows the deviation/dispersion/variation from the mean. It is a measure of risk, the higher the standard deviation, the higher the risk. The standard deviation is a measure that summarizes the amount by which every value within a dataset varies from the mean. It is the most robust and widely used measure of dispersion. Skewness indicates the symmetry of the distribution. A skewed distribution which is positive indicates scores that are clustered to the left, and the tail of the distribution extending to the right while a negatively skewed distribution demonstrates scores that are clustered to the right and the tail of the distribution extends to the left. Kurtosis on the other hand, defines the peak of the distribution. Positive kurtosis is indicated by a peak. Negative kurtosis is indicated by a flat distribution. The data set in table 1 showed that the data set were normally distributed. Concerning the normality tests; skewness and kurtosis of the models showed that the data were normal. 
TABLE 1: Descriptive statistics

\begin{tabular}{|c|c|c|c|c|c|c|c|c|c|c|c|}
\hline Construct & Mean & Median & Maximum & Minimum & $\begin{array}{l}\text { Std. } \\
\text { dev }\end{array}$ & Skewness & Kurtosis & $\begin{array}{l}\text { Jarque- } \\
\text { Bera }\end{array}$ & Sum & $\begin{array}{l}\text { Sum sq } \\
\text { Dev }\end{array}$ & Observations \\
\hline ECA & 0.664 & 0.652 & 0.821 & 0.261 & 0.276 & 2.132 & 6.424 & 9.372 & 6.321 & 0.234 & 121 \\
\hline GMA & 0.198 & 0.189 & 1.212 & 0.121 & 0.336 & 1.602 & 4.521 & 4.868 & 2.180 & 0.215 & 121 \\
\hline ROE & 9.872 & 9.552 & 11.021 & 9.862 & 0.010 & -0.382 & 2.167 & 0.723 & 80.421 & 5.118 & 121 \\
\hline ROA & 9.762 & 7.731 & 9.341 & 6.121 & -0.165 & 0.012 & 1.421 & 1.122 & 60.261 & 8.065 & 121 \\
\hline
\end{tabular}

Source: E-Views output, 2021

TABLE 2: Panel least square regression analysis between environmental cost accounting and financial performance of oil and gas companies

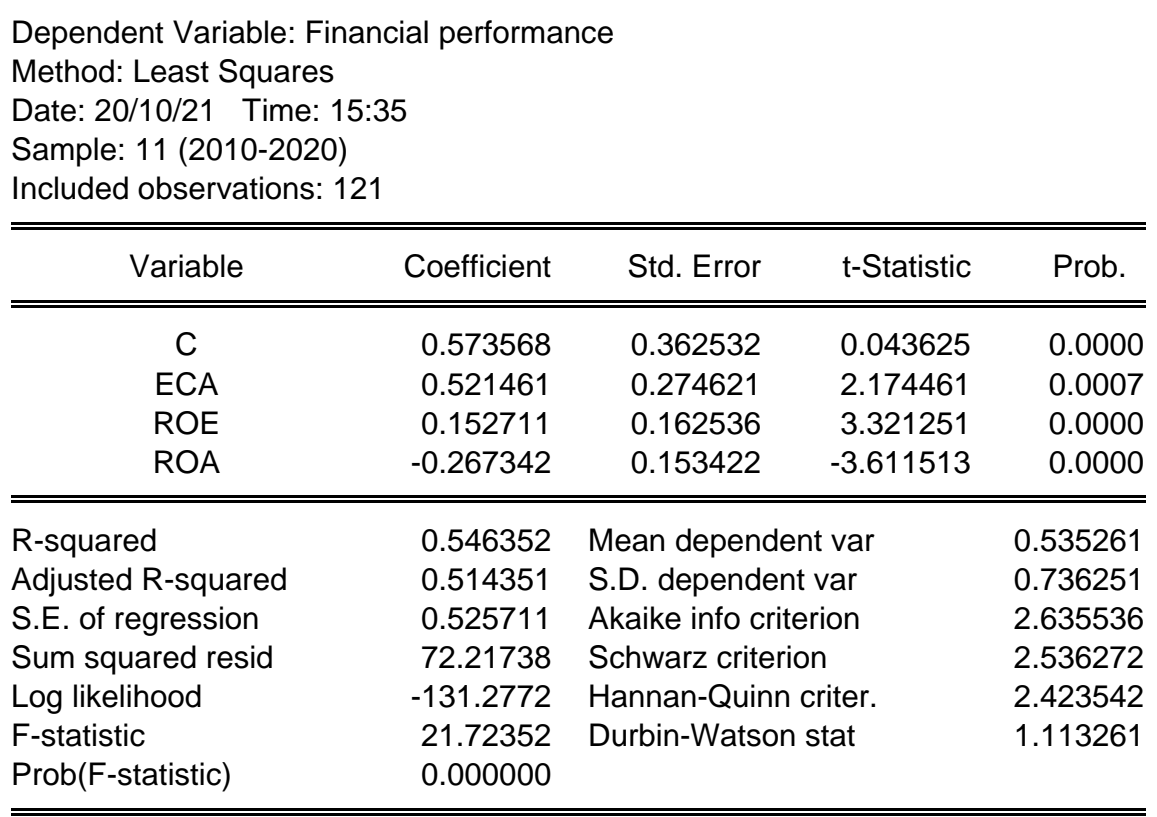

Source: E-Views 9.0 Output, 2021

The model shows that ECA, ROE and ROA significantly affect financial performance of oil and gas companies. The results also indicate that, ECA, ROE and ROA are all 
significant at $5 \%$ level of significance. This result implies that the more oil and gas companies spent money on the environment, the better their performance. Serial correlation is proved to be absent based on the Durbin-Waston statistic result of 1.113261. Based on the results therefore, the study rejects the null hypothesis that environmental cost accounting has significant effect on the financial performance of oil and gas firms. Moreover, the model summary of the regression results shows the combined effect of ECA, ROE and ROA variables on the financial performance of the selected oil and gas companies as shown by the $\operatorname{Prob}($ F-statistic $)=0.000000$, to be statistically significant at $5 \%$ level. The combined R2 which is the coefficient of determination is 0.51 . This means that $51 \%$ of the financial performance of the selected oil and gas companies is explained by ECA, ROE and ROA while the remaining $49 \%$ is explained by other factors outside the model.

\section{Decision}

Going by the result of the analysis, which reports that $\operatorname{Prob}(\mathrm{F}$-statistic $)=0.000000$ is less than the critical P-value of 0.05 , thus, $\mathrm{H} 1$ is accepted and Ho is rejected. The implication of this result is that environmental cost accounting has significant positive effect on the financial performance of Oil and Gas Companies at 5\% level of significance.

TABLE 3: Fixed effect model between ECA, ROE and ROA

Dependent Variable: Financial performance

Method: Least Squares

Date: 20/10/21 Time: 15:35

Sample: 11 (2010-2020)

Cross-section included: 11

Included observations: 121

\begin{tabular}{crrrr}
\hline \hline Variable & Coefficient & Std. Error & z-Statistic & Prob. \\
\hline \hline C & 0.035263 & 0.883884 & 1.153672 & 0.2145 \\
ECA & 0.432182 & 0.032221 & 2.423425 & 0.0023 \\
ROE & 0.062845 & 0.178034 & 0.239732 & 0.0124 \\
ROA & -0.179177 & 0.151722 & -2.343023 & 0.0008 \\
\hline \hline
\end{tabular}

Effects specification

Cross-section fixed (dummy variable

\begin{tabular}{llll}
\hline \hline R-squared & 0.2554916 & Mean dependent var & 0.204325 \\
Adjusted R-square & 0.1764783 & S.D. dependent var & 0.007382
\end{tabular}




\begin{tabular}{llll} 
S.E. of regression & 0.7005335 & Akaike info criterion & 2.343526 \\
Sum squared resid & 67.584940 & Schwarz criterion & 2.088521 \\
Log likelihood & -124.3782 & Hannan-Quinn criter & 2.743532 \\
F-statistic & 8.0735361 & Durbin-Watson stat & 1.231324 \\
Prob(F-statistic) & 0.0000001 & & \\
\hline \hline
\end{tabular}

Source: E-Views 9.0 Output, 2021

TABLE 4: Hausman specification test for hypothesis one

Correlated random effects: Hausman test

Equation: Untitled

Date: 20/10/21 Time: 15:37

Test: Cross-section random effect

\begin{tabular}{lccc}
\hline \hline Test summary & Chi-Sq. Statistic & Chi-Sq. d.f. & Prob. \\
\hline \hline Cross-section random & 10.712452 & 3 & 0.0001 \\
\hline \hline
\end{tabular}

Source: E-Views 9.0 Output, 2021

Interpretation of Hausman specification test

Based on the result of the Hausman specification test in table 4, the p-value of the test was 0.0001 , which was statistically significant at the conventional level of 0.05 . Thus, the Fixed Effect Model (FEM) in table 3 confirm and validated as the preferred model in analysing the effect of environment cost accounting on the financial performance of Oil and Gas Companies in Nigeria at 5\% level of significance. Thus, further confirming the result that environment cost accounting has significant effect on the financial performance of Oil and Gas Companies in Nigeria

TABLE 5: Panel least square regression analysis between green management accounting and financial performance of oil and gas companies

\begin{tabular}{|c|c|c|c|c|}
\hline Variable & Coefficient & Std. Error & t-Statistic & Prob. \\
\hline C & 0.473563 & 0.662511 & 4.443625 & 0.0000 \\
\hline GMA & 0.221464 & 0.254623 & 7.174432 & 0.0000 \\
\hline ROE & 0.062713 & 0.162542 & 3.321251 & 0.0000 \\
\hline ROA & -0.067344 & 0.151421 & -0.341513 & 0.6321 \\
\hline & 0.722463 & Mron don & it var & 0.435523 \\
\hline Adjusted R-squared & 0.632352 & S.D. depende & var & 0.767537 \\
\hline
\end{tabular}




\begin{tabular}{lrll} 
S.E. of regression & 0.725722 & Akaike info criterion & 2.635536 \\
Sum squared resid & 61.21722 & Schwarz criterion & 2.636221 \\
Log likelihood & -122.2711 & Hannan-Quinn criter. & 2.432541 \\
F-statistic & 22.72333 & Durbin-Watson stat & 1.103252 \\
Prob(F-statistic) & 0.000000 & & \\
\hline \hline
\end{tabular}

Source: E-Views 9.0 Output, 2021

Table 5 shows the empirical effect of green management accounting on the financial performance of oil and gas companies in Nigeria. The Beta Coefficient value for the variables reveal that: $\operatorname{GMA}(\beta 1)=0.221464 ; \operatorname{ROE}(\beta 2)=0.062713 ; \operatorname{ROA}(\beta 3)=-0.067344$. The slope coefficient; $\mathrm{P}(\mathrm{xi}=0.0000 ; \mathrm{x} 2=0.0000 ; \mathrm{x} 3=0.6321)$. Using the $\mathrm{T}-\mathrm{Ratio}$ to test for their statistical significance, it was found that GMA and ROE variables were statistically significant at 5\% level. This is due to the fact that their observed T-values are positive and above the "rule of thumb of 2 . The other variable (ROA) is statistically non-significant because the observed tvalue is either negative or far less than the rule of thumb of 2 . However, the results of the hypothesis test shows that GMA, ROE, ROA accounts for $63.2 \%$ of the changes in the financial performance of oil and gas companies while $36.8 \%$ are attributed to other factors not included in the model. The F-statistic $=22.72333$ with its associated Prob(F-statistic $)=$ 0.000000 implies that the overall joint effect of GMA, ROE, and ROA on financial performance of oil and gas companies was statistically significant at 5\% level

\section{Decision}

Going by the rule of thumb, Hi was accepted while Ho was rejected, since the P-value of the equation is 0.000000 which is less than the critical value of $0.05(5 \%)$. This implies that green management accounting has a significant positive effect on the financial performance of oil and gas firms in Nigeria at 5\% level of significance.

Table 6: Fixed effect model between GMA, ROE and ROA

Dependent Variable: Financial performance

Method: Least Squares

Date: 20/10/21 Time: 17:35

Sample: 11 (2010-2020)

Cross-section included: 11

Included observations: 121 


\begin{tabular}{lrrrr}
\multicolumn{1}{c}{ Variable } & Coefficient & Std. Error & z-Statistic & Prob. \\
\hline \hline C & 0.035263 & 0.912283 & 3.183972 & 0.0002 \\
GMA & 0.432182 & 0.232566 & 6.423462 & 0.0000 \\
ROE & 0.062845 & 0.178628 & 5.239692 & 0.0000 \\
ROA & -0.179177 & 0.163177 & -0.443065 & 0.5128 \\
\hline \hline \multicolumn{5}{c}{ Effects specification } \\
\hline Cross-section fixed (dummy variable & & \\
\hline \hline & \multicolumn{5}{c}{0.354746} \\
R-squared & 0.4583676 & Mean dependent var & 0.738252 \\
Adjusted R-square & 0.4764772 & S.D. dependent var & 2.443543 \\
S.E. of regression & 0.7005351 & Akaike info criterion & 2.785634 \\
Sum squared resid & 65.584952 & Schwarz criterion & 2.243556 \\
Log likelihood & -122.3776 & Hannan-Quinn criter & 1.231432 \\
F-statistic & 11.073566 & Durbin-Watson stat & \\
Prob(F-statistic) & 0.0000000 & & \\
\hline \hline
\end{tabular}

Source: E-Views 9.0 Output, 2021

Table 7: Hausman specification test for hypothesis two

Correlated random effects: Hausman test

Equation: Untitled

Date: $20 / 10 / 21$ Time: 15:37

Test: Cross-section random effect

\begin{tabular}{lccc}
\hline \hline Test summary & Chi-Sq. Statistic & Chi-Sq. d.f. & Prob. \\
\hline \hline Cross-section random & 10.572245 & 3 & 0.0002 \\
\hline \hline
\end{tabular}

Source: E-Views 9.0 Output, 2021

Interpretation of Hausman specification test

Based on the result of the Hausman specification test in table 7, the p-value of the test was 0.0002 , which was statistically significant at the conventional level of 0.05 . Thus, the Fixed Effect Model (FEM) in table 6 confirm and validated as the preferred model in analysing the effect of green management accounting on the financial performance of Oil and Gas Companies in Nigeria at 5\% level of significance. Thus, further confirming the result of hypothesis two that environment cost accounting has significant effect on the financial performance of Oil and Gas Companies in Nigeria.

\subsection{Discussion of findings}

This study examined the effect of green environmental accounting on the financial performance of listed oil and gas companies Nigeria with the period of 2010-2020. The 
model for testing hypotheses 1 showed that ECA, ROE, ROA significantly affect financial performance of listed oil and gas companies in Nigeria. The results also indicate that ECA, ROE and ROA are all significant at 5\% level of significance. This result implies that the more the Nigerian oil and gas companies spent money on the development of its operating environment, the better their financial performance. Serial correlation is proved to be absent based on the Durbin-Waston statistic result of 1.113261. Based on the analysis results therefore, this study rejected the null hypothesis that environmental cost accounting does not have a significant effect on the financial performance of performance of oil and gas companies in Nigeria. Moreover, the model summary of the regression results shows the combined effect of ECA, ROE and ROA variables on the financial performance of oil and gas companies as shown by the Prob(F-statistic) $=0.000000$, to be statistically significant at $5 \%$ level. The combined R2 which is the coefficient of determination was 0.51 . This means that $51 \%$ of the financial performance of oil and gas companies is explained by ECA, ROE and ROA while the remaining $49 \%$ is explained by other factors outside the model. The finding was supported by Chiamogu \& Okoye (2020) who found that environmental cost has significant effect on the financial performance of oil and gas companies in Nigeria. Also, the finding was inline with the study of Saman (2019), who found that environmental accounting has significant effect on the financial performance of oil and gas companies in Nigeria. Corroborating with the findings of the study, Almalik (2020) indicated that green accounting enhances environmental performance of organisation.

From the test of hypothesis two, the Beta coefficient value for the variables revealed that: $\operatorname{GMA}(\beta 1)=0.221464 ; \operatorname{ROE}(\beta 2)=0.062713 ; \operatorname{ROA}(\beta 3)=-0.067344$. The slope coefficient; $\mathrm{P}(\mathrm{xi}=0.0000 ; \mathrm{x} 2=0.0000 ; \mathrm{x} 3=0.6321)$. Using the $\mathrm{T}$ - Ratio to test for their statistical significance, it was found that GMA and ROE variables were statistically significant at 5\% level. This was due to the fact that their observed T-values are positive and 
above the rule of thumb of 2 . The other variable (ROA) was statistically non-significant because the observed t-value is either negative or far less than the rule of thumb of 2 . However, the results of the analysis showed that GMA, ROE and ROA accounts for $63.2 \%$ of the changes in the financial performance of oil and gas companies while the remaining $36.8 \%$ were attributed to other factors. The F-statistic $=22.72333$ with its associated Prob(Fstatistic) $=0.000000$ implies that the overall joint effect of GMA, ROE, and ROA on financial performance of oil and gas companies was statistically significant at $5 \%$ level. The study was supported by the findings of Eze (2021) who found that green accounting reporting have significant effect on the financial performance of manufacturing firms in Nigeria. Also, the finding from the study was supported by Nkwoji (2021) study who found that environmental accounting has significant effect on the profitability of quoted oil and gas companies in Nigeria.

\section{Conclusion}

The green accounting is an emerging aspect of accounting science that will influence, in the near future. The adoption of basic elements of green accounting will portray the role of environment in the economy as well as render easier the analysis of macroeconomic questions with the help of green accounting measures and thus, will lead the economy to a viable path. However, the study explored the effect of green accounting on the financial performance of oil and gas companies in Nigeria. Two dimensions of green or environmental accounting were chosen for the study: environmental cost accounting and green management accounting. The results from the analyses showed that the two constructs of green accounting influenced the financial performance of oil and gas firms measure by return on equity and return on asset. Specifically, the study concluded that environmental cost accounting has significant effect on financial performance of oil and gas companies in Nigeria. Similarly, 
green management accounting has a significant effect on financial performance of oil and gas companies in Nigeria. Based on the findings of the study, it is concluded that adequate green or environmental could enhance the operating environment of the firm as well as the financial performance of oil and gas firms.

\section{$6 \quad$ Recommendations}

Based on the findings, the following recommendations were proffered:

1. Management of oil and gas companies in Nigeria should pay particular attention to environmental cost accounting to enhance the firm's operating environment and the financial performance of the companies. Also, since most oil and gas companies hardly report their environmental activities, the government should make environmental reporting in annual reports compulsory thereby passing legislation which will compel companies to integrate environmental issues into their strategic planning process; and the publication of environmental accounting standards both locally and internationally which can be reviewed continually to ensure dynamism in compliance.

2. Management of oil and gas companies should effective green accounting to reduce the impact of the firm's operation on the environment. Also, oil and companies should ensure that they comply with the environmental laws of the nation as it will go a long way in enhancing their performances.

3. Oil and gas companies should ensure environmental awareness within the host communities in order to create a cordial relationship between the companies and the host communities. Also, oil and gas companies should design their operation to reduce waste or emission during their operations. 


\section{REFERENCES}

Almaliki, N. (2020). Impact of green accounting on improving environmental costs and performance: An analytical study from an academic point of view. International Journal of Engineering Technology Research \& Management, 4(3), 127-143.

Arafat, M.Y., Warokka, A., \& Dewi, S.R. (2012). Does environmental performance really matter? A lesson from the debate of environmental disclosure and firm performance. Journal of Organizational Management Studies, 1(1), 1-15.

Astuti, N. (2012). Mengenal green accounting. Journal Permana, 4(1), 69-75.

Bassey E. B., Sunday O. E., \& Okon E. E. (2013). The impact of environmental accounting and reporting on organizational performance of selected oil and gas companies in Niger Delta region of Nigeria. Research Journal of Finance and Accounting, 33(3), 56-71.

Chiamogu, A., \& Okoye, J. (2020). Environmental cost and financial performance of oil and gas companies in Nigeria. International Journal of Advanced Academic Research, 6(10), 1-24.

Chinwe, A. S. (2013). The impact of environmental pollution in Imo State: a case study of Okigwe local government area. Journal of Educational and Social Research, 3(5), 7979. 
Cortez, M.A., \& Cudia, C.P. (2011). Sustainability and firm performance: A case study of Japanese electronics companies. Ritsumeikan International Affairs,. 10, 321-340

Eilola, M. (2017). The link between corporate environmental performance and corporate financial performance. Masters thesis submitted to Jyväskylä University School of Business and Economics, 1-67.

Eze, E. (2021). Green accounting reporting and financial performance of manufacturing firms in Nigeria. American Journal of Humanities and Social Sciences Research, 5(7), 179187.

Eze, J. C., Nweze, A. U. \& Enekwe, C. I. (2016). The effects of environmental accounting on a developingnation: Nigerian experience. European Journal of Accounting, Auditing and Finance Research, 4 (1), 17-27.

Ezeagbea, C. E., John-Akamelu, C. R., \& Umeoduagu, C. (2017). Environmental accounting disclosures and financial performance: A study of selected food and beverage companies in Nigeria. International Journal of Academic Research in Business and Social Sciences, 7(9), 162-174

Gray, R. (2002). The social accounting project and accounting, organizations and society: privileging engagement, imaginings, new accountings and pragmatism over critique? Accounting, Organizations and Society, 27, 687-708

Gray, R., \& Laughlin, R. (2012). It was 20 years ago today: Sgt Pepper, accounting, auditing $\&$ accountability journal, green accounting and the blue meanies. Accounting, Auditing \& Accountability Journal, 25(2), 228-255.

Hecht, J. E. (2012). National environmental accounting: Bridging the gap between ecology and economy. Cambridge: Routledge.

Iliemena, R. O. (2020). Environmental accounting practices and corporate performance: Study of listed oil and gas companies in Nigeria. European Journal of Business and Management, 12(22), 58-70.

Iliemena, R. O. C. \& Okolocha, C. B. (2019). Effect of audit quality on financial performance :evidence from a developing capital market. International Journal of Recent Research in Commerce Economics and Management (IJRRCEM), 6(3), 191-198

Johnson-Rokosu, S.F \& Olanrewaju, R.A (2016). Corporate sustainability reporting practice in an emerging market: A case of listed companies in Nigeria. "Dimitrie Cantemir" Christian University Knowledge Horizons - Economics 8(2), 148-156.

Khan, M. A., \& Ghouri, A. M. (2011). Environmental pollution: Its effects on life and its remedies. Researcher World: Journal of Arts, Science \& Commerce, 2(2), 276-285.

Lewis, A., \& Chopparapu, B. (2017). Corporate environmental reporting and the financial Profitability of listed manufacturing firms in Nigeria. International Journal of Advanced Academic Research Social \& Management Sciences, 3(8), 15-25

Magnaghi, E,\& Aprile, R (2014). A theoretical perspective on this critical issue of business and economics. Journal of Integrated Reporting, 5(8), 1320-1337. 
Makori D., \& Jagongo A. (2013). Environmental accounting and firm profitability: An empirical analysis of selected firms listed in Bombay stock exchange, India. International Journal of Humanities and Social Science, 3(18), 103-114

Malik, P., \& Mittal, A. (2015). A study of green accounting practices in India. Disclosure, $4(6), 45-67$

Menike L. (2020). Impact of Environmental Disclosure on Firm Performance: An Empirical Analysis of Food, Beverage and Tobacco Sector Companies Listed in Colombo Stock Exchange, Sri Lanka,L. (2020). International Journal of Academic Research in Business and Social Sciences, 10(10),518-536

Minimol, M. C., \& Makesh, K. G. (2014). Green accounting and reporting practices among Indian corporates. Asia Pacific Journal of Research, I (14), 143-165.

Moorthy, K., \& Yacob, P. (2013). Green accounting: Cost measures. Open Journal of Accounting, 2(1), 4-7.

Nas, T. F. (2016). Cost-benefit analysis: Theory and application. London: Lexington Books.

Nkwoji, N. (2021). Environmental accounting and profitability of selected quoted oil and gas companies in Nigeria. Journal of Accounting and Financial Management, 7(3), 22-39.

Nwaiwu, N. J. \&Oluka, N. O. (2018). Environmental cost disclosure and financial performance of oil and gas in Nigeria. International Journal of Advanced Academic Research, 4 (2), 1 - 23.

Ochotorena, R. (2017). Green accounting: Integrating environmental impact to financial reporting framework. Journal of Business \& Economic Studies, 11(1), 1-21

Ogoun1 S. Ekpulu G. A. (2020). Environmental Reporting and Operational Performance: A Study of Listed Manufacturing Firms in Nigeria. International Journal of Intellectual Discourse, 3(1), 381- 396

Okafor, G. O. (2018). Environmental Costs Accounting and Reporting on Firm Financial Performance: A Survey of Quoted Nigerian Oil Companies. International Journal of Finance and Accounting, 7(1), 1-6.

on sustainable development in Nigeria. Research Journal of Finance and Accounting, 3(7), $65-72$.

Olusegun, M.V. (2012). The impact of corporate environmental responsibility on financial performance: Perspective from the multinational extractive sector. A thesis submitted to Brunel Business School, Brunel University.

Oti, P. A. \& Mbu-Ogar, G. B. (2018). Analysis of environmental and social disclosure and financial performance of selected quoted Oil and Gas Companies in Nigeria (20122016). Journal of Accounting and Financial Management, 4(2), 1 - 12. 
Oti, P.A., Effiong, S.A., \& Tiesieh, T.A. (2012). Environmental costs and its implication on the returns on investment: An evaluation of selected manufacturing companies in Nigeria. Global Journal of Management and Business Research, 12(7), 1-5

Pariag-Maraye, N., Ansaram, K., \& Ramkalawon, N.D. (2017). Environmental management systems and financial performance: The case of listed companies in Mauritius. Scientific Research, 7(7), 1-14

Phong, T.H., Hue, C.T., \& Thu, H.N. (2012). Impact of firms environmental performance on its financial performance: Empirical evidence from Vietnam ${ }^{\text {ee }}$ small and medium manufacturing firms. 2012 JSPS Asian CORE Program, Nagoya University and VNU University of Economics and Business.

Portney, K. E. (2013). Taking sustainable cities seriously: Economic development, the environment, and quality of life in American cities. London: MIT Press.

Rewadikar, B. (2014). Green accounting. IRJA-Indian Research Journal,1(2), 7-14.

Saman, U. P. (2019). Environmental Accounting and Financial Performance of Oil and Gas Companies in Nigeria. Research Journal of Finance and Accounting, 10(10), 192-201

Uwuigbe, U., \& Jimoh, J. (2012). Corporate environmental disclosures in the Nigerian manufacturing industry: A study of selected firms. African Research Review-An International Multidisciplinary Journal, Ethiopia 6 (3), 71-83.

Virola,R. A., De Perio, S. M., \& Angeles, E. T. (2000). Paper presentation users' forum on environmental accounting, Skytop, Hotel Intercontinental Makati City 29 June 